\title{
ESTRUCTURA DRAMÁTICA Y RECURSOS TEATRALES EN EL ROMANCERO TRADICIONAL
}

\author{
Santiago TRANCÓN \\ I.E.S. Calderón de la Barca (Madrid) \\ ramir@inicia.es
}

Resumen: Se propone una interpretación de los romances medievales teniendo en cuenta los elementos teatrales presentes, no sólo en la actuación de los juglares, sino en la misma estructura textual y narrativa de estas composiciones, que hasta ahora han sido estudiados casi exclusivamente desde el punto de vista literario o épico-lírico. Se parte del supuesto de que los romances eran recitados, declamados, cantados y presentados ante un público en directo, lo que implicaba asumir e integrar en el texto los elementos propios de la representación teatral.

Abstract: The interpretation proposed here is based on medieval ballads performance characteristics. It embraces the presentation of jugglers as well as the narrative and structure of texts. Current studies only have been conducted either from literary or epic-lyric perspectives. This proposal stands on the assumption that ballads were performed through reciting, singing and acting in front of a live audience, in which the process of integration between the text itself and the performance has occurred. 
Palabras clave: Baladas medievales. Texto. Teatro. Performance. Épico-lírico.

Key words: Medieval ballads. Text. Theatre. Performance. Epic-lyric.

\section{INTRODUCCIÓN}

La mayoría de los estudios sobre el Romancero parte de unos supuestos generales que, con ligeras variantes, se repiten una y otra vez sin ponerse en duda. Así, por ejemplo, casi todos los autores dan por aceptado que los romances tienen un origen posterior a la lírica y a la épica, sin que existan realmente argumentos sólidos para una afirmación tan categórica, salvo la existencia de fuentes documentales indirectas, claramente insuficientes en todo lo que se refiere al estudio de una época en la que la cultura escrita era, en sentido estricto, una rareza. Igualmente se acepta, por ejemplo, el carácter predominantemente narrativo del Romancero, o épico-lírico, sin prevención alguna sobre la proyección de una distinción de géneros literarios bastante ajena al fenómeno mismo de los romances, a su origen, difusión y pervivencia.

Las preocupaciones de otros estudiosos se suelen dirigir a constatar el carácter histórico o novelesco de los romances tradicionales, las variantes lingüísticas y locales, su difusión, etc., por un lado y, por otro, a la investigación sobre aspectos temáticos y formales relacionados con su estructura lírica, narrativa, rítmica, las técnicas descriptivas y de composición. Se parte de una consideración predominantemente textual y literaria de los romances, sin plantearse abordar aspectos más generales relacionados con las formas concretas de producción y transmisión de los romances, o sea, con todo aquello que tenga que ver con el público receptor y con la actividad específica de juglares, cantores, actores o cualquier otro «actuante» $\mathrm{o}$ «creador» de los romances. Al perder de vista el fenómeno mismo, o sea, el acto a través del cual los romances tomaban vida, se creaban y transmitían a un público interesado, una parte fundamental del sentido y carácter del Romancero se deja de lado por completo, estableciendo una visión puramente literaria basada en el estudio de los textos escritos, recogidos y transmitidos a partir de los siglos XV y XVI. El fenómeno de los romances y los romances mismos, con toda su variedad, se convierte en el Romancero, y el Romancero en obra o texto literario, forzando su unidad, su origen, su sentido y su carácter literario, e ig- 
norando el fenómeno mismo (la creación y difusión del romance, su función y recepción, y todo lo que esto implica).

Las referencias al contenido y desarrollo teatral -y, por tanto, creativo, efímero, funcional e indisolublemente ligado a la recepción- de los romances, se toman, en el mejor de los casos, como simples añadidos de carácter histórico o sociológico, sin ponerlos en relación con la estructura, el lenguaje, las formas lingüísticas y compositivas del romance mismo. Ignorar esto, sin embargo, lleva necesariamente a errores de bulto, así como a no comprender alguno de los problemas que, desde el punto de vista puramente literario o textual, plantean la mayoría de los romances.

\section{EL ROMANCERO: LITERATURA, TEXTO Y GÉNERO LITERARIO}

La primera reflexión que propongo tiene que ver con la caracterización conceptual y general que del Romancero se ha hecho a partir del siglo XVI y que ha consagrado la Historia de la Literatura, especialmente a través de los análisis y estudios llevados a cabo desde principios del siglo XX. El Romancero se ve, antes que nada y casi de forma exclusiva, como literatura, texto literario y, a partir de estas categorías, como poesía épico-lírica.

Si bien, desde el punto de vista metodológico, es legítimo que la Literatura defina previamente su objeto y lo categorice, estableciendo así los límites que justifican la especificidad de su análisis, no puede este principio imponerse sobre la realidad de hechos que, lejos de producirse conforme a categorías previas, han tenido un desarrollo enteramente ajeno a esas categorías. El concepto moderno de literatura, texto y género literario, es muy posterior al origen, desarrollo y expansión de los romances, por lo que cometemos un error histórico y metodológico si los consideramos y analizamos partiendo exclusivamente de esos conceptos. Si los romances fueran sólo o esencialmente textos literarios escritos, nada podríamos objetar a la mayoría de los enfoques y estudios llevados a cabo hasta ahora. Pero creemos que los romances fueron, antes que nada, un fenómeno o hecho teatral, espectacular o artístico, y que es dentro de esta consideración más general - y previaen la que caben otros enfoques o análisis más específicos o limitados, como puede ser el estudio de su contenido textual y literario.

Los estudiosos de la literatura medieval, conscientes de la extrapolación de conceptos propios de la historia y teoría literaria de otro tiempo, a un pe- 
ríodo que sólo forzadamente encaja dentro de esas categorías, acuñaron el término «literatura oral» con el que, en principio, parecían obviarse las limitaciones y descontextualizaciones a las que se veían frecuentemente obligados a llevar a cabo. Pero el concepto de literatura oral se presta a no pocas confusiones. Parece oponerse al de «literatura escrita», pero resulta difícil concretar en qué se opone, si se trata simplemente de una diferencia en las formas de transmisión (oralidad frente a escritura), de un origen distinto (creador colectivo frente a creador individual), de contenidos diferenciados (temas populares frente a temas cultos), o de estructuras narrativas, de composición y lenguaje distintos. Con frecuencia se mezclan estos criterios, lo que ya de por sí pone de manifiesto la ambigüedad o confusión a la que se presta el término literatura oral.

Si analizamos con un poco de detención esta serie de oposiciones, sin embargo, nos damos cuenta de su poca consistencia. En efecto, oralidad no se opone a escritura, por ejemplo. El que los romances se recitaran, cantaran, «actuaran» o interpretaran (a lo que de forma simplificada podemos llamar «oralidad»), no quiere decir que no se escribieran previamente en manuscritos y que esos manuscritos no circularan entre juglares, cantores o actores. Que luego esos romances quedaran en la memoria de las gentes (de ciegos, recitadores, o improvisados juglares) allí donde los juglares profesionales los mostraban, cantaban e interpretaban, es otra cosa. Que a partir de esa memoria popular, los romances se fueran adaptando, cambiando, mezclando y fragmentando de acuerdo al gusto de sus oyentes-espectadores y de juglares más o menos espontáneos, es un hecho que prueba la vitalidad de los romances y el gusto de un público que gozaba con todo lo que en torno a los romances se producía: cantos, bailes, improvisaciones, actuaciones e interpretaciones más o menos teatralizadas. Lo que sí podemos establecer es que, en una posible jerarquía de hechos, el carácter «oral» (o sea, el romance como fenómeno «teatral» y popular) era el dominante, de modo que la escritura se supeditaba a la oralidad y no al revés. Que luego, a partir del siglo XV o XVI, se produjera el fenómeno inverso, el de supeditar la «oralidad» a la escritura, o sea, convertir a los romances en literatura, es también un hecho históricamente concreto y que requiere un estudio y explicación específicos, pero que no puede hacernos olvidar el origen y la realidad misma de los romances medievales y su relación con el público al que iban dirigidos.

El concepto actual de literatura, por otro lado, nace ligado al de escritura (littera, letra), y la escritura, a partir de la imprenta, quedó igualmente asociada al libro como objeto material y espiritual a un tiempo, de tal modo que no podemos concebir la literatura sin el libro, en el que esa literatura queda 
objetivada, publicada (hecha pública) y abierta, por tanto, a la difusión y lectura por parte de cualquiera. Con la escritura y el libro, la literatura se va desvinculando poco a poco de su oralidad, o sea, del hecho de que los textos escritos en su mayoría tenían en cuenta que iban a ser leídos en voz alta o cantados, más que destinados a la lectura individual, privada y silenciosa. $E l$ Quijote es, quizás, el último gran libro en el que su autor tiene más en cuenta la lectura oral (lo que influye en los ritmos respiratorios, la sintaxis, el lenguaje, las imágenes, la comprensión inmediata del texto, etc.) que una lectura privada, subvocal o inarticulada. Gran parte de la poesía, además, era escrita teniendo en cuenta no sólo su oralidad, sino su musicalidad, ya que la poesía inicialmente no se distingue del canto o la canción; el simple recitado, incluso, siempre fue una forma de canción sometida ritmos y curvas melódicas que iban mucho más allá de la simple lectura.

Queremos decir con todo esto que, si bien nada impide que hagamos extenso el concepto de literatura para incluir en él a todas las manifestaciones artísticas (escritas u orales) relacionadas con el uso estético, emotivo y no funcional del lenguaje (concepto actual), no podemos olvidar que no existía este concepto como tal en la Edad Media y que, por tanto, los romances no eran considerados en aquella época como literatura, o sea, como textos destinados exclusivamente a producir un goce artístico o emocional, superfluo, basado en la función estética del lenguaje y transmitido fundamentalmente a través de la lectura. Eran más bien producciones, realizaciones, actuaciones y espectáculos destinados a divertir, recrear fantasías colectivas, producir identificaciones de grupo, transmitir valores e ideas morales, políticas y religiosas, etc., utilizando para ello un arte, el arte de juglaría, arte para el que se necesitaban no sólo habilidades poéticas y lingüísticas, sino de actuación (recitado, canto, danza, interpretación de personajes, toque de instrumentos musicales, etc.). Así que el concepto de literatura, en lo que se refiere a la Edad Media, debemos integrarlo dentro de un concepto o visión mucho más amplia, la que se refiere a la actividad de los juglares y las juglaresas, para quienes, por ejemplo, la distinción entre romances y canciones de gesta (distinción literaria más que práctica), no debía tener importancia o significación alguna. No negamos, por tanto, que los romances sean literatura y texto literario, pero afirmamos que estos conceptos deben tomarse en un sentido muy amplio e integrarse, a su vez, en conceptos más generales y más ajustados a la realidad de los hechos que estamos analizando, en los que intervienen elementos no sólo literarios, sino teatrales.

Pero no sólo la oposición oralidad/escritura resulta poco apropiada para el estudio de los romances; algo parecido podemos afirmar sobre las otras di- 
cotomías con las que se trata de definir el concepto de literatura oral: popular/culto, colectivo/individual.

La separación entre temas y formas cultas/temas y formas populares, es una separación en gran medida arbitraria e imposible de diferenciar en lo que se refiere a la cultura y literatura medievales. Esta distinción sólo empieza a ser pertinente a partir de finales del siglo $\mathrm{XV}$, en todo caso, cuando se consolida el ocio de una nobleza caballeresca con gustos y formas de vida que aspiran cada vez más a distinguirse de las del pueblo llano. Basta leer a Berceo o al Arcipreste de Hita (supuestos autores cultos), para darnos cuenta de que no es posible manejar con seriedad la distinción entre literatura culta/literatura popular en la Edad Media. El afán de diferenciarse de algunos autores cultos por la perfección de su arte, nada afecta a los contenidos y formas del arte que escriben. El público al que se dirigen, por otro lado, es el mismo, y desde este punto de vista pocas diferencias se podían establecer. Más aún, la literatura española se caracteriza a lo largo de toda su historia por una mezcla constante entre lo popular y lo culto y por más que lo diferenciemos, resulta muchas veces imposible establecer esta distinción, ya que no podemos atribuir con facilidad el origen de temas y formas a autores concretos frente a otros anónimos, creaciones individuales frente a tradiciones populares, y más bien comprobamos con frecuencia una interacción fecunda e indistinguible entre lo popular y lo culto. (¿Quién puede separar lo que Lope le debe al pueblo de lo que el pueblo le debe a Lope ${ }^{1}$ ?)

La oposición entre origen individual/origen colectivo, resulta igualmente poco productiva y confunde más que aclara el problema de la distinción entre literatura oral y literatura escrita. La afirmación más cuestionable es la del origen colectivo de los romances. El que los romances circulen libremente, se modifiquen por sucesivos juglares, que unos y otros, receptores y animadores, vayan añadiendo y quitando versos, no significa en modo alguno que podamos hablar de autor colectivo. Podemos imaginar autores sucesivos, pero siempre individuales, que van creando y recreando romances con total libertad, revitalizándolos constantemente. Ni el pueblo es su autor, ni los autores sucesivos modifican los romances por simple gusto o arbitrariamente, entre otras cosas, porque la profesión de juglar nació de la especialización para me-

${ }^{1}$ La relación de Lope de Vega con los romances está por estudiar desde el punto de vista que aquí propongo. Si aceptamos el carácter teatral de muchos romances, nada debe extrañarnos que Lope acabara teatralizándolos del todo, bien construyendo con ellos algunas de sus más famosas comedias o tragedias (El caballero de Olmedo, por ejemplo), bien inspirándose en la eficacia teatral del arte de juglaría, que tanto entusiasmó al público medieval y al de su tiempo, para crear su «arte nuevo». 
morizar grandes parrafadas de versos, más que por ser creadores originales de los mismos. El anonimato de estos textos es una prueba, no a favor de la autoría colectiva, sino de la fidelidad a una tradición que exigía una habilidad memorística especial, aquélla de la que los juglares hacían gala al recordar y recrear cuantos más romances mejor. Sin duda, el receptor (el pueblo) es un creador indirecto de los romances, en la medida en que su gusto, sus reacciones e intereses, movían a los juglares a enfatizar determinados temas y adoptar fórmulas, estilos, vocabulario, etc.; pero este es otro tema.

En cuanto a la adscripción de los romances a un género literario concreto - poesía narrativa o épico-lírica —, es fruto igualmente de un reduccionismo que arranca de las premisas anteriormente puestas en duda. Lo más equivocado de este enfoque es que ignora los aspectos relacionados con la escenificación de los romances, o sea, que se limita al texto y, dentro de él, sólo a parte de sus componentes (estructura narrativa, elementos líricos), dejando de lado la estructura dramática, los recursos teatrales, las relaciones con el público, elementos escénicos e interpretativos, etc., todo lo cual es imprescindible, no sólo para hacernos una idea más acertada de lo que en realidad eran los romances, cómo se producían y transmitían, sino para entender el texto mismo, lleno de referencias y elementos sólo plenamente comprensibles desde esta perspectiva global, escénica o teatral.

Lo que proponemos, por tanto, es interpretar los romances desde el punto de vista del teatro, o sea, considerar el texto en función de su representación escénica. Cuando hablamos de teatro no estamos refiriéndonos sólo a un género literario más (el género dramático), sino a una práctica artística en la que el texto no tiene autonomía literaria, ya que está en función de la representación, en la que de verdad cobra su significado pleno. El texto teatral no contiene a toda la representación, por lo que hemos de suponer muchas veces elementos escénicos que configuran un contexto no explícito, pero necesario para que el significado textual adquiera su verdadero sentido:

El arte del juglar no era ni es un arte de textos escritos (aunque pudiera valerse de ellos) sino de palabra hablada. El buen juglar, como el buen actor, sería aquel que, más allá de reproducir un texto, vivía y hacía vivir a su público una determinada historia. (...) El buen juglar debe ser capaz de comunicar, por todos los medios a su alcance (palabra, canto, pantomima), una situación, una idea o un sentimiento (Díaz G. Viana, 1998: 39).

Si aplicamos estas consideraciones a los romances, hemos de aceptar que el texto conservado, no sólo es fragmentario o incompleto por sí mismo, 
sino porque le faltan todos los elementos teatrales y escénicos en los que ese texto adquiría su sentido y existencia plena, por lo que nuestra aproximación actual necesariamente ha de ser incompleta. Hemos de hacer un esfuerzo para imaginar todo lo que le falta a los romances, o sea, todo lo referente a su escenificación, además de la parte del texto desaparecida. Estudiar los romances sin tener en cuenta esto lleva a privilegiar los aspectos narrativos y líricos presentes en el texto, frente a los teatrales y los ausentes. No queremos decir con esto que los romances no contengan elementos épicos y líricos muy destacados y fundamentales, sino que estos elementos se integraban de forma natural en un esquema teatral global, la actuación que los juglares hacían ante un público al que atraían y entretenían con infinidad de recursos escénicos y teatrales (música, cantos, danzas, saltos, cambios de voz, caracterización de personajes, movimiento escénico, mímica, malabarismos, etc.), en relación directa con ese público, al que tenían que emocionar, fascinar, asombrar y moralizar a un tiempo. Un público, por lo demás, entregado, conocedor de gran parte de las historias que se contaban, cantaban y escenificaban, y al que le interesaba, tanto o más que la historia misma, las habilidades del juglar para dar vida a esa historia y hacérsela presente, no sólo en su imaginación, sino sobre el improvisado espacio escénico donde actuaba:

La comparación entre juglaría y teatro no es arbitraria. Como realizaciones representadas «para» $y$ «con» un público por profesionales de la voz y del gesto son actividades próximas entre sí. Lo que nos interesa en comprender que las obras del juglar o que el juglar difunde se crean desde un esquema abierto a la invención o innovación de cada actuación (Díaz G. Viana, 1998: 40).

No resulta, por tanto, muy apropiado el hablar de géneros literarios para analizar o comprender los romances medievales. En todo caso, podemos hablar de poesía para referirnos, más que a un género literario, a una actitud vital, al modo como las gentes de esta época vivían los sentimientos y las emociones, de forma bastante más natural y espontánea de lo que podemos hoy imaginar. Sobre el sentido de la poesía en la Edad Media escribe Juan Victorio: «La comunicación de entonces era mayoritariamente poética, ya fuera para llamar a la guerra, para sugerir la castidad, para mover a la generosidad e incluso para poder solicitar un vaso de «bon vino» (Victorio, 1995: 28). Las relaciones que el hombre de la Edad Media mantenía con la naturaleza, el amor, el sexo, el cuerpo, la belleza, la amistad, la fidelidad, el valor, el bien, el mal, etc., no eran, en modo alguno, las de hoy, pero tampoco estaban tan sometidas al dogma y la religión como tendemos a creer, sino 
que nacían de un fondo más natural, instintivo y pagano del que con frecuencia suponemos:

La represión erótica que, se supone, dominaba en la Edad Media, se daba sólo en la cabeza de algunos eclesiásticos, o de quienes se les parecían. Pero una cosa es que hubiera represión como doctrina y otra muy diferente que la gente, incluso la gente eclesiástica, siguiera tal doctrina (Victorio, 1995: 29).

Siguiendo el consejo de este autor, mejor será, por consiguiente, que tratemos de leer los romances no desde el género, sino desde el texto mismo, entre otras razones porque, como dice Mercedes Díaz Roig, «en un solo texto pueden coexistir lo histórico, lo novelesco y lo lírico» (1986: 23); y lo teatral, añadimos nosotros.

\section{EL ROMANCERO Y LOS ROMANCES}

\subsection{Variedad temática $y$ formal}

El primer problema que se nos plantea, al iniciar el estudio concreto de los romances, es el de delimitar el origen medieval o no de los romances que decidamos analizar. Sabemos que los romances comenzaron a reescribirse a principios del siglo XVI. Pero esta fecha es muy posterior al origen del romance como forma de comunicación y de creación artística. El tiempo transcurrido entre el período álgido de creación y vitalidad de los romances y este de su transcripción escrita es de varios siglos, por lo que sólo podemos tomar con precaución estos textos escritos, si de lo que tratamos es de conocer y recrear lo que el romance fue realmente en su momento originario. Los estudios lingüísticos y algunos hechos con documentación histórica nos permiten aventurar hipótesis cronológicas para algunos de los romances, pero no para la mayoría. Como el objeto de este trabajo no es investigar estos problemas, seguiremos en esto la cronología general más aceptada, limitándonos al estudio a alguno de los romances viejos o tradicionales más conocidos.

El segundo problema, relacionado con la hipótesis de la teatralidad del Romancero, es el de la unidad de los romances. Hablar del Romancero Viejo o Tradicional como de una manifestación artística y cultural unificada, con forma y estructura definida, es algo arbitrario. Los romances no tienen ni forma ni estructura únicas, ni unidad de temas, ni de extensión; su conser- 
vación, además, es muy irregular y tampoco podemos establecer fechas de composición que nos permitan diferenciarlos claramente para analizar su evolución, etc. Escribe Díaz Roig: «Lo fantástico, lo maravilloso, lo extraordinario, lo real y lo cotidiano, conviven codo con codo en los textos, textos que tienen una variedad tonal y temática amplísima» (1986: 29). Y más adelante:

La libertad que existe en temas y duración interna existe en la manera de narrar. El carácter mismo del romance, con su mezcla de «noticia» y «cuento» permite presentar junto a los motivos principales que van desarrollando la trama, los secundarios que «adornan» lo que se está relatando. Además, el creador se siente sin ninguna traba para contar su historia, ya que no hay una manera preestablecida que dicte cómo tratar cada tipo de motivo o cada situación; los textos que el poeta popular tiene en la memoria le ofrecen toda una serie de posibilidades de plasmación (Díaz Roig, 1986: 32).

Esta falta de unidad temática y formal ${ }^{2}$ se pone de manifiesto en los intentos frustrados de establecer una clasificación «científica» o rigurosa de los romances. Ni los criterios temáticos ni los cronológicos parecen resultar adecuados, ya que dan lugar a un sinnúmero de clasificaciones superpuestas (históricos, noticieros, fronterizos, épicos, líricos, caballerescos, novelescos, viejos, de tradición oral moderna, etc.). Tampoco otros criterios logran resolver el problema. Diego Catalán (1997), por ejemplo, habla de romances «viejos, juglarescos, trovadorescos y eruditos».

Ante estos hechos, lo más sensato parece acercarnos a los textos sin prejuicios ni limitaciones previas, tratando de imaginar qué podía ocurrir cuando los juglares actuaban ante un público como el de la Edad Media, del que ya hemos dicho que se parecía poco al que solemos imaginar y suponer. ¿Qué podían hacer los juglares con su arte, en qué podía consistir ese arte, qué formas y recursos necesitaban emplear para lograr, ante todo, que el público atendiera y se divirtiera al máximo para que luego, en recompensa, les dieran cobijo, algo de comer y de beber, y quizás alguna moneda para su sustento?

2 «El romance admite toda clase de temas: la guerra, la rebelión, el heroísmo, la tradición, el amor, el adulterio, la fidelidad, la aventura y la muerte. Los temas, motivos, situaciones y circunstancias se repiten, pero cada romance (y muchas veces cada versión) es único. Las fuentes de sus asuntos están, tanto en la historia de España, como en la novela europea y bizantina, la épica francesa, los cuentos y leyendas folklóricas, la balada europea y, por supuesto, en la propia imaginación del poeta que toma elementos de aquí, de allá y de él mismo» (Díaz Roig, 1984: 31). 
El arte y el oficio juglaresco, lejos de ser una actividad sencilla, como si el juglar fuera un simple recitador, era más bien una profesión en la que existía una gran variedad de formas y modos de ejercerla. Escribe Luis Díaz G. Viana:

Bajo el amplio manto de la juglaría se movían muy variados tipos de artista que iban del creador poético al equilibrista o al payaso, pasando por instrumentistas de toda clase (trompeteros, dulzaineros, tamborileros, vihuelistas, etc.), malabaristas y amaestradores de animales. En aquella tropa había juglares de distinto menester, posición social, sexo (no olvidemos a las cantaderas y soldaderas) y raza, ya que en España existió juglaría de cristianos y de moros (1990: 35).

Habla también este autor de juglares «cazurros», que contaban chistes, refranes, recitaban y cantaban fragmentos poéticos..., y de los «cedreros» (tocaban la cedra), que eran juglares que recorrían Castilla a caballo y gozaban de gran estima. Según Díaz G. Viana, juglares y trovadores, juglaría y clerecía no eran oficios opuestos ni estaban incomunicados. Había incluso formas de contar que iban unidas a ciertos instrumentos, así como también existían juglares muy instruidos, tal y como se ve en el Libro de Alexandre.

Como vemos, a la gran variedad y amplitud temática y cronológica, hemos de añadir la diversidad de formas de creación, producción y transmisión de unos textos que unían a la flexibilidad narrativa una gran maleabilidad de recursos de escénicos, teatrales. Todo esto sólo es posible porque el juglar no se somete a una fórmula textual cerrada, ni su función se limita a dar noticia de algo o ser un mero cronista de hechos del pasado, sino que sirve a, o cumple una diversidad de funciones, y todo ello a través de una variedad de recursos a los que podemos denominar globalmente como «teatralidad». Dice acertadamente Díaz Roig: «El juglar no se siente de ninguna manera obligado a transmitir una visión exacta del pasado, sino una visión poética de él. Sin embargo, lo que relata tiene que ser verosímil y estar afincado en una realidad» (1984: 20).

La verosimilitud es uno de los elementos teatrales que permite la identificación del público con la historia escenificada. Pero esa verosimilitud, añadimos, no ha de ser necesariamente realista, sino escénica, teatral y poética. Los romances no responden a la lógica histórica, ni buscan ser fieles a una idea de objetividad totalmente ajena a la mentalidad de la época. Si interpretamos los romances desde el punto de vista de la noticia o la transmi- 
sión de hechos históricos, frente a la que oponemos lo novelesco o la leyenda, estamos haciendo una proyección de nuestro modo de entender lo histórico y la realidad que en nada preocupaba a los hombres de aquella época, mucho más interesados en dejarse arrastrar por sentimientos y emociones puras, directas, por la fantasía y la magia, no opuestas al concepto de realidad con el que construían el interpretaban el mundo de cada día. Conviene tener esto en cuenta para no tildar con demasiada ligereza a algunos romances de ingenuos, novelescos o fantásticos, frente a otros históricos y realistas.

Pero pasemos a estudiar esos elementos y recursos teatrales de los que hablamos y con los que el romance se constituye como tal y crea una fórmula artística original, no encuadrable en ningún género literario, sino que es expresión de una comunicación abierta y directa con el público y para la que se utilizan multitud de formas: poéticas, narrativas, musicales y teatrales.

\subsection{Estructura y recursos teatrales}

La esencia de lo dramático es mostrar o presentar ante un público algo como si estuviera ocurriendo en ese momento. Se juega a la ficción de hacer realidad un hecho imaginario. Los acontecimientos se re-presentan, a través de la acción directa, sobre un espacio real, durante un tiempo real y ante espectadores de carne y hueso. Lo dramático siempre ocurre en el presente de los espectadores, aunque los sucesos escenificados se refieran a un tiempo pasado. En los romances, los sucesos no suelen presentarse simplemente como algo del pasado - algo contado, ocurrido hace tiempo-, sino que, a través de multitud de recursos, el juglar los trae al presente de los espectadores, aunque nunca se rompa la conciencia de ser un relato de acontecimientos de un pasado más o menos cercano, remoto o imaginario.

Podemos hablar de la estructura dramática de los romances en dos sentidos: uno, externo, que consiste en el hecho mismo de que el juglar se convierte, al hablar, cantar e interpretar la narración directamente ante el público, en un actor, en alguien que representa e interpreta una historia. Es un narrador-personaje o un personaje-narrador que da vida a una historia utilizando todo tipo de recursos escénicos, visuales y sonoros. Esa historia se teatraliza en la medida en que se presenta y representa ante un público en un espacio y un tiempo concretos. Adquiere, por tanto, la estructura o forma teatral de la presentación, independientemente del contenido y la estructura literaria del texto recitado, cantado o interpretado. 
En el arte el juglar, como en cualquier «arte vivo», cara al público, mucho más importante que la coherencia estructural —según un crítico textualista la entiende—o que la perfección de la forma, es el «efecto»; un «efecto» bello que impresione, que llegue al espectador, que conmueva o encorajine es lo que el juglar persigue. Su performance, que, por supuesto, no carece de estructura ni de logros formales, va encaminada al logro de ese efecto, al logro de un público hechizado por el canto o por la palabra (Díaz G. Viana, 1998: 34).

Pero también podemos hablar de la estructura dramática interna del texto mismo en la medida en que ese texto incorpora el hecho de la representación, o sea, el hecho de que va a ser presentado ante un público. Todos los romances son, en este sentido, la representación dramática de un suceso ejemplar, lo que se plasma en una estructura interna guiada o condicionada por lo dramático y lo teatral.

Para ser más claros, forzando un poco los términos, podemos hablar de teatralización, por un lado, para referirnos a la dramatización externa de los romances (el canto, los gestos, la música, los malabarismos, la danza, etc., todo lo que se refiere a la actuación del juglar y que transforma el romance en espectáculo) y de teatralidad, por otro, que sería la dramatización interna del relato, basada en el texto mismo y que convierte al juglar en personaje (o en multitud de personajes) a través de la interpretación y que transformaría al romance en representación.

Los romances, desde esta perspectiva, podían estar (y pueden estarlo sus textos) más o menos teatralizados y más o menos dramatizados, del mismo modo que podemos hablar de romances más o menos líricos o épicos. En el romance, poesía, narración y dramatización no se oponen, sino que se funden en un entramado original, guiados por el hecho de la teatralización o presentación ante un público. Poesía, narración y dramatización serían recursos entremezclados, utilizados indistintamente por el juglar para lograr el interés y la fascinación del público. Los romances, siguiendo este enfoque, serían a la vez relatos y dramas poetizados, poemas y relatos dramatizados y poemas y dramas narrados. Lo importante siempre era el efecto sobre el espectador, potenciar al máximo su atención, su disfrute, sus emociones y su imaginación. En este sentido es en el que decimos que lo teatral era lo dominante, el factor que condicionaba a todos los demás. Por eso los juglares podían hablar, recitar, cantar e interpretar los textos, pasando de una forma a otra con habilidad para mantener vivo el interés del público. Se irían adaptando para ello a las distintas partes del texto, que a su vez se vería influido por las dis- 
tintas formas de actuación y presentación. Fragmentos recitados, fragmentos cantados, fragmentos teatralizados: así, con riqueza y variedad de recursos, mezclándolos con maestría, el juglar crearía su arte y su mester. Para ello podía transformar el texto, acortarlo o alargarlo, dar una nueva versión a un tema antiguo, buscar el aplauso y el gusto de público acercando la historia en el tiempo y en el espacio, o trasladándola a la época de los héroes legendarios. Todo era posible. Los romances mismos podían acabar en baile y en fiesta, o acompañar al baile y la fiesta. El romance serviría así para muchas cosas: ser puro entretenimiento, diversión y chanza, difundir noticias y hechos de interés colectivo, recrear un pasado heroico, propagar ideas y valores, fomentar identidades colectivas, despertar emociones, asombrar, fascinar, producir un disfrute estético, propiciar encuentros, evadirse del trabajo y el dolor, etc. En su evolución, los romances empezaron a servir, incluso, de entretenimiento para eruditos, nobles y nuevos ricos ociosos. De aquí nacen los Cancioneros y Romanceros de mediados del siglo XVI.

Hasta Menéndez Pidal, que presupone, con argumentos no muy convincentes, el origen posterior de los romances con relación a la epopeya (los cantares de gesta), reconoce el carácter teatral de romances y canciones de gesta:

Al reflejar la situación escogida de la gesta, o el asunto de un romance amplio, el poeta popular prefiere, más que narrar los hechos, actualizarlos, expresando una emoción efectiva o la impresión sensual recibida entre la acción que imagina como presente a los ojos... (...) Las palabras que cada persona dice manifiestan su acción como en el drama, de modo que ni siquiera es preciso anunciar quién es el interlocutor. Romances hay que suprimen toda acción para quedar reducidos a un mero diálogo dramático (Citado en Díaz G. Viana, 1998: 54-55).

\subsection{Análisis de algunos romances}

Pasemos a analizar, por último, algunos romances, en los que veremos de forma concreta reflejado cuanto hemos venido afirmando hasta aquí.

Romance del cerco de Baeza

Cercada tiene a Baeza / ese arráez Andalla Mir, con ochenta mil peones, / caballeros cinco mil. Con él va ese traidor, / el traidor de Pero Gil.

Por la puerta de Bedmar / la empieza de combatir; 
ponen escalas al muro, / comiénzanle a conquerir; ganada tiene una torre, / no le pueden resistir, cuando de la de Calonge / escuderos vi salir.

Ruy Fernández va delante, / aquese caudillo ardil, arremete con Andalla, / comienza a le ferir, cortado le ha la cabeza, / los demás dan a fuir ${ }^{3}$.

En primer lugar, llama la atención el uso del tiempo verbal en este breve romance: todos los verbos estén en presente de indicativo. El juglar no sólo cuenta, sino que escenifica, dramatiza, hace presente el relato, la historia. No se trata de un mero recurso literario (el presente histórico de la narración), sino teatral. El juglar quiere hacer ver a los espectadores los hechos como si estuvieran presenciándolos realmente. El juglar se convierte en un personaje de esa historia, un espectador real de sucesos que finge (teatro) estar viendo en esos momentos. Los ve como espectador privilegiado (el espectador teatral) que puede contemplar lo que sucede muy de cerca y en el momento en que sucede, pero al mismo tiempo desde fuera. Por eso en un momento llega a decir «escuderos vi salir», utilizando la primera persona. Hemos de suponer que el juglar acompañaría con gestos, mímica, saltos, canto y música (acción) este breve relato para hacérselo al público lo más atractivo, vivo y entretenido posible. En algún momento podría actuar como Ruy Fernández y blandir una espada ante el público y quién sabe, a lo mejor hacía aparecer mágicamente la cabeza sangrante de Andalla, provocando la sorpresa o el espanto entre el público.

La estructura teatral afecta, por tanto, no sólo en la presentación, recitado o canto del texto por parte del juglar (teatralidad externa), sino a su representación (dramaticidad interna), y como prueba de esta representación encontramos marcas textuales claras, difícilmente explicables atendiendo sólo a su estructura épica. La narración, en cambio, sí determina la organización o tratamiento del transcurso temporal, acelerando el tiempo, condensándolo y sintetizándolo. El desarrollo temporal, en este sentido, es más narrativo que teatral.

La fórmula textual, por tanto, es una mezcla de relato y representación, de cuento escenificado y de suceso contado. La estructura y los recursos teatrales son inherentes y esenciales, en todo caso, para la construcción y la comprensión del texto mismo.

3 Todos los romances están tomados de El Romancero viejo, Mercedes Díaz Roig (1984). 
Moricos, los mis moricos...

Moricos, los mis moricos, / los que ganáis mi soldada, derribédesme a Baeza, / esa ciudad torreada,

y los viejos y las viejas / los meted todos a espada, y los mozos y las mozas / los traeden en la cabalgada, y la hija de Pero Díaz / para ser mi enamorada, y a su hermana Leonor / de quien sea acompañada. Id vos, capitán Vanegas / porque venga más honrada, porque enviándoos a vos / no recelo en la tornada que recibiréis afrenta, / ni cosa desaguisada.

Este romance se nos presenta enteramente teatralizado, en estilo directo. Ya no es el juglar quien, convertido en personaje-narrador, nos cuenta la historia. Aquí habla directamente un personaje, un caudillo moro. El juglar que actúa ante el público interpreta a este personaje, toma su voz y habla como tal al auditorio. El personaje caudillo se dirige a otros personajes imaginarios, pero presentes: primero a sus soldados y luego a uno de sus capitanes. Todo el romance es como una escena teatral en la que un caudillo arenga a sus soldados y da órdenes precisas. Su parlamento nos revela su personalidad, su carácter, y nos remite a acciones en las que sus palabras toman sentido. Habla en imperativo y en presente. Podemos imaginar sus gestos, su vestuario, su voz, todo aquello que el juglar-actor encarnaría para dar realismo y verosimilitud a los versos. La intervención del personaje no tiene un narrador que introduzca sus palabras. El texto, al carecer de narrador, se dramatiza formal e internamente.

Romance de Abenámar

- iAbenámar, Abenámar, / moro de la morería, el día que tú naciste / grandes señales había!

Estaba la mar en calma, / la luna estaba crecida, Moro que en tal signo nace / no debe decir mentira.

Allí respondiera el moro, / bien oiréis lo que diría:

-Yo te la diré, señor, / aunque me cueste la vida, porque soy hijo de un moro / y una cristiana cautiva; siendo yo niño y muchacho / mi madre me lo decía que mentira no dijese / que era grande villanía; por tanto pregunta, rey, / que la verdad te diría.

-Yo te agradezco, Abenámar, / aquesta tu cortesía. ¿Qué castillos son aquéllos? / ¡Altos son y relucían! - El Alhambra era, señor, / y la otra la mezquita, los otros los Alixares, / labrados a maravilla. 
El moro que los labraba / cien doblas ganaba al día,

$Y$ el día que no los labra, /otras tantas se perdía.

El otro es Generalife, / huerta que par no tenía, el otro Torres Bermejas, / castillo de gran valía.

Allí habló el rey don Juan, / bien oiréis lo que decía:

- Si tú quisieses, Granada, / contigo me casaría;

daréte en arras y dote / a Córdoba y a Sevilla.

- Casada soy, rey don Juan, / casada soy, que no viuda;

el moro que a mí me tiene / muy grande bien me quería.

No vamos a hablar del contenido ni el sentido poético de este romance, tan estudiado y conocido. Nos bastará destacar la existencia de un diálogo teatral entre dos personajes, un rey primero - que luego se convierte en el rey don Juan-, y Abenámar, un moro hijo de cristiana cautiva. Empieza hablando el rey, dirigiéndose a Abenámar en estilo directo. Contesta el moro, y esta vez su parlamento viene introducido por la voz del narrador, que utiliza una fórmula común a los romances y a los cantares de gesta. Vuelve a intervenir el rey directamente, sin nexo introductor. Contesta Abenámar de nuevo como en cualquier diálogo teatral, sin fórmula introductoria. El romance acaba con la inclusión de otro diálogo, seguramente proveniente de otro romance: ahora es el rey Juan quien habla con Granada, a la que personifica, y quien contesta al rey que ya está casada con un moro «que la tiene»y «muy grande bien» la quiere ${ }^{4}$.

En este romance, la estructura narrativa apenas existe, y la presencia del narrador es mínima. Hablan personajes, a los que podemos fácilmente ver representando su papel sobre un escenario. En general, los romances utilizan mucho la enumeración descriptiva, siempre muy visual. El que sea la descripción un elemento tan destacado es una prueba sobre lo que podríamos llamar dramatización del relato. La descripción así utilizada adquiere un valor teatral, en la medida en que sirve para que los espectadores puedan

${ }^{4}$ El fenómeno de la personificación de las ciudades, todas en femenino, es llamativo en el Romancero y bien puede ser una prueba a favor del fenómeno contrario: que el nombre de algunas ciudades encubra o simbolice el nombre de alguna mujer, tal y como opina Juan Victorio. Mujeres y ciudades parecen igualmente cercadas, defendidas, acosadas, asaltadas y vencidas, y no parece violentar demasiado el sentido poético de los romances el aceptar esta interpretación. «Todas las ciudades o fortalezas citadas en estos romances tienen nombre de género femenino... No hay, pues, nada noticiero, sino relato que se presenta a la nobleza de la reconquista de una mujer casada o con compromiso (o como esté): con muchos riesgos. Como advertencia, es tan bella como útil. Y si, además, hay quienes están tentados y se lanzan arma en mano a tomar ciudades o castillos, predicar la cruzada resulta innecesario. Hay un ejemplo ilustre de esta conducta: el poeta Jorge Manrique, que vivió en esos mismos años, murió en el asedio de otro castillo. ¿Pensaba que iba a encontrar solamente un «morico»? » (Victorio, 1995: 107-108). 
construir fácilmente el escenario de los hechos y los pormenores más significativos de la acción, tal y como hacen con frecuencia los personajes de la comedia de Lope, que crean así lo que se ha llamado el decorado verbal de la obra.

La alternancia verbal, por otro lado, es otra de las características de éste y otros romances, que nos indica esa mezcla textual de relato y representación, tan original y casi exclusiva de los romances.

Romance de Nuño Vero

—iNuño Vero, Nuño Vero, / buen caballero probado!

hinquedes la lanza en tierra / y arrendedes el caballo, preguntaros he por nuevas / de Baldovinos el franco.

-Aquesas nuevas, señora, / yo vos las diré de grado:

Esta noche, a media noche, / entramos en cabalgada

y los muchos a los pocos / lleváronnos de arancada.

Hirieron a Baldovinos / de una muy mala lanzada,

la lanza tenía dentro, / de fuera le tiembla el asta;

su tío, el emperador, / a penitencia le daba;

o esta noche morirá, / o de buena madrugada.

Si te plugiese, Sebilla, / fueses tú mi enamorada;

adamédesme, señora, / que en ello no perderéis nada.

— iNuño Vero, Nuño Vero, I mal caballero probado!

yo te pregunto por nuevas, I tú respondésme al contrario,

que aquesta noche pasada / conmigo durmiera el franco;

él me diera una sortija, / y yo le di un pendón labrado.

La estructura y presentación de este romance es enteramente dialogal. Hablan dos personajes, Nuño Vero y Sebilla. Es curiosa la ambigüedad entre el nombre de la ciudad y el nombre de la señora, amante de Baldovinos el franco. La escena tiene una fuerte tensión y progresión dramática: la amante pregunta por su amado, Baldovinos, a Nuño Vero, "ibuen caballero proba$d o$ !». Nuño Vero le da malas noticias: su amante está a punto de morir. Pero Nuño aprovecha este momento tan doloroso para declararse a la dama, como si se alegrara de la muerte de Baldovinos. La dama reacciona ofendida y ya Nuño Vero se convierte en «imal caballero probado!». El final acentúa el dramatismo al recordar la dama que la noche pasada había dormido con Baldovinos y ella le había entregado «un pendón labrado» y él «una sortija». El sentido simbólico y sexual de estos regalos parece evidente, aunque estén invertidos los términos: ella le entrega su cuerpo (la sortija) y él su virilidad (el pendón labrado). 
Como puede verse, en este romance no existe tampoco narrador, y debemos imaginar al juglar encarnando sucesivamente a los dos personajes, uno masculino y otro femenino. El juglar actor debería hacer visible y audible la diferencia entre el parlamento de cada uno de estos dos personajes mediante recursos teatrales (¿voz, mínima, movimientos, algún elemento de vestuario, diferentes melodías?), y la eficacia dramática y poética del romance dependería en gran parte de su capacidad interpretativa y de sus dotes actorales.

Arriba, canes, arriba...

¡Arriba, canes, arriba! / ique rabia mala os mate!

En jueves matáis el puerco / y en viernes coméis la carne.

Ay, que hoy hace los siete años / que ando por este valle, pues traigo los pies descalzos, / las uñas corriendo sangre, pues como las carnes crudas / y bebo la roja sangre, buscando, triste, a Julianesa, / la hija del emperante, pues me la han tomado moros, I mañanica de San Juan, cogiendo rosas y flores / en un vergel de su padre.

Oído lo ha Julianesa, I que en brazos del moro está, las lágrimas de sus ojos / al moro dan en la faz.

Este hermoso romance es casi todo él un monólogo teatral. Habla el amante de Julianesa, desesperado: buscando a su amada se ha vuelto salvaje, como los canes a los que grita. La figura del moro es la del oponente, actante imprescindible en toda escena dramática de amores. Hemos de señalar que es muy llamativa la presencia de los moros y la morería en todo el Romancero, pues no se limita a los llamados romances fronterizos, sino que aparece profusamente en todos los demás: épicos, novelescos, líricos... Esto sólo se puede interpretar en sentido simbólico, no realista. La figura del moro y la morería creo yo que no hay que entenderla en clave social, histórica o sociológica, como si se refirieran constantemente los romances a las disputas políticas y religiosas de la mal llamada Reconquista. El moro es el oponente, el otro, al que se admira tanto como se rechaza, y no tanto los árabes musulmanes pobladores de gran parte de España durante siglos.

La imagen final del romance, la dama dejando caer sus lágrimas sobre la faz del moro, es de un lirismo dramático de gran fuerza teatral. Julianesa, antes virgen (ha sido raptada «mañanica de San Juan / cogiendo rosas y flores / en un vergel de su padre»), está ahora haciendo el amor con el moro mientras su verdadero amor da gritos muy cerca, desesperado. Obsérvese, de nuevo, el uso del presente de indicativo, lo que convierte la escena en real, viva, teatral: Julianesa «está» en brazos del moro y sus lágrimas «dan» en su rostro. 
Lanzarote y el orgulloso

Nunca fuera caballero / de damas tan bien servido como fuera Lanzarote / cuando de Bretaña vino, que dueñas curaban de él, / doncellas del su rocino. Esa dueña Quintañona, I ésa le escanciaba el vino, la linda reina Ginebra / se lo acostaba consigo; y estando al mejor sabor, / que sueño no había dormido, la reina toda turbada / un pleito ha conmovido:

- Lanzarote, Lanzarote, / si antes hubieras venido, no hablara el orgulloso / las palabras que había dicho, que a pesar de vos, señor, / se acostara conmigo. Ya se arma Lanzarote / de gran pesar conmovido, despídese de su amiga, / pregunta por el camino. Topó con el orgulloso / debajo de un verde pino, combátense de las lanzas, / a las hachas han venido. Ya desmaya el orgulloso, / ya cae en tierra tendido. Cortárale la cabeza, / sin hacer ningún partido; vuélvese para su amiga / donde fue bien recibido.

La estructura textual de este romance parece más narrativa que teatral. Sin embargo, hemos de hacer la siguiente precisión: lo narrativo responde aquí más a una visión teatral, escénica, representativa, de la historia, que propiamente narrativa. En realidad, apenas hay historias en los romances, salvo en los romances largos, donde el desarrollo de hechos y sucesos toma un carácter más novelado o de relato. En el resto de los romances conservados, sin embargo, casi siempre se nos presentan o representan escenas, cuadros teatrales con una acción condensada, de la que se destacan sólo los elementos más dramáticos (para lo que se poetiza y dramatiza la descripción y la narración, que adoptan formas concisas, muy visuales, como buscando la percepción directa de los sentidos; es una descripción y narración, podríamos decir en relieve), para componer la escena. En todo caso se trata de una narración no «novelada», en el sentido de que lo narrativo en el cuento y la novela tiene un tempo, un ritmo y un tono más alargado, de mayor extensión espacio-temporal que el relato contenido en los romances.

Una prueba del carácter teatral de este romance es el diálogo que la reina dirige a su amante, colocado en medio del texto, presentado sin ningún verbum dicendi. Al hablar así, la escena se hace presente ante los espectadores que oyen y ven actuar al juglar. La acción que sigue se nos presenta con una economía descriptiva y narrativa admirable: Lanzarote vence al ofensor de su amiga y le corta impecablemente la cabeza. 
Nótense dos cosas: a la dama amante se la llama «amiga», como en la lírica de las cantigas (no debieron estar tan separados romances, cantigas y cantares de gesta) y es la reina, la mujer, quien a Lanzarote «se lo acostaba consigo». En todo momento el protagonismo y la iniciativa la toma la mujer, que es quien incita al hombre a dar muerte al orgulloso. El hombre debe mostrar su hombría y virilidad venciendo a los rivales, o de lo contrario no es nadie ante la mujer a la que ama.

Yo me levantara, madre...

Yo me levantara, madre, / mañanica de san Juan, vide estar una doncella / ribericas de la mar.

Sola lava y sola tuerce, / sola tiende en un rosal; mientras los paños se enjuagan / dice la niña un cantar: - Do los mis amores, do los, / ¿dónde los iré a buscar? Mar abajo, mar arriba, / diciendo iba un cantar, peine de oro en las sus manos / y sus cabellos peinar:

-Dígasme tú, el marinero, / que Dios te guarde de mal, si los viste a mis amores, / si los viste allá pasar.

Éste es uno de lo muchos romances que presenta claras conexiones con la canción lírica. En primer lugar, el «narrador» es un personaje; no es el juglar quien se dirige al público directamente. Este personaje (que puede ser el marinero del final, o una mujer que habla a su madre) cuenta lo que vio, que enseguida transforma en lo que «ve», haciéndolo presente imaginario ante los oyentes-espectadores: "sola lava y sola tuerce, / sola tiende en un rosal». Habla en primera persona, luego estamos ante un texto en estilo directo, o sea, formalmente teatral.

Aparece luego cantando el personaje central, una doncella llena de tristeza y desconsuelo, que acaba preguntando por sus amores a un marinero, que no responde. La escena queda así, en suspense, dominada por el dramatismo de esa canción sin respuesta de la doncella.

Estamos ante otra escena teatralizada y dramatizada. Para comprenderla y disfrutar estéticamente de su contenido tenemos que, en cierto modo, imaginarla teatralmente, o sea, construir un espacio escénico de ficción (orillas del mar), donde vemos a una doncella lavando su ropa, peinándose y preguntando a un marinero por «sus amores» ${ }^{5}$. No hay narración, sino una es-

\footnotetext{
5 Nótese que en los romances más antiguos y en la lírica medieval casi siempre se habla de «amores» y no de «amor». Con ello se hace referencia, más que al sentimiento del amor o el enamoramiento, en sen-
} 
cena y una acción interpretada por un personaje, la doncella. El romance se podría teatralizar de muchas maneras (podemos suponer que el juglar cantaría la canción de la doncella acompañándose de un instrumento musical), pero el texto mismo está ya dramatizado en su estructura y en la forma teatral que adopta, independientemente de los recursos teatrales que luego el juglar empleara para hacerla más atractiva ante el público.

Compañero, compañero...

-Compañero, compañero, / casóse mi linda amiga, casóse con un villano, / que es lo que más me dolía.

Irme quiero a tomar moro / allende la morería, cristiano que allá pasare / yo le quitaré la vida.

-No lo hagas, compañero, / no lo hagas, por tu vida.

De tres hermanas que tengo / darte he yo la más garrida, si la quieres, por mujer, / si la quieres, por amiga.

-Ni la quiero por mujer, / ni la quiero por amiga, pues que no pude gozar / de aquella que más quería.

Otro romance estructurado a partir de un diálogo puro, sin narrador ni verbos introductorios. Hablan dos personajes y aquí el juglar, para distinguir sus parlamentos, necesariamente tendría que interpretar o encarnar, al menos a través de la voz, a cada uno de estos personajes diferentes. El estilo es directo y la escena en presente. El sentido dramático nace de la desesperación del

tido moderno, a la expresión de emociones y sentimientos mucho más vitales y espontáneos, en los que el amor no está separado del cuerpo y de la satisfacción sexual. Los amores «se tienen», se hacen, se viven, son, ante todo, «placer», «placeres», y el desconsuelo de la doncella nace, no de la pérdida «del amor», sino porque su amigo la ha abandonado después de gozar de ella. Parece claro el sentido simbólico y metafórico de la escena y de la mayoría de sus elementos: una joven ha perdido su virginidad y ha sido luego abandonada por su amante, al que busca inútilmente. ¿Qué sentido puede tener, si no, ese lavar y retorcer la ropa sola, tenderla en un «rosal», peinar sus cabellos despeinados, y preguntar a un marinero si vio «pasar» a sus amores? La escena ocurre junto al mar, cuyas olas son siempre símbolo de virilidad, esa fuerza que se lleva la «doncellez» de las jóvenes que luego lloran o hacen confidencias a su madre. Todo sucede, además, «mañanica de San Juan». En la noche de San Juan toda doncella «ha de tener amores», según una tradición pagana y medieval extendida por toda la Península. Sobre el valor y sentido del símbolo en la literatura medieval escribe Juan Victorio: «El símbolo se tenía que imponer como medio de expresión (que no tenía por qué ser exclusivamente poético), arruinando a los otros recursos antes citados (la comparación y la metáfora son muy poco empleadas) porque es el más apto para identificar (los otros, en definitiva, relacionan dos cosas diferentes) y, para el tema que estamos considerando, el amoroso desde el punto de vista físico, no se puede concebir mejor manera de gozar de él que identificándose con la naturaleza, haciéndose parte integrante suya, produciéndose así una mentalidad de «panteísmo humano», muy lógica por otra parte entre quienes viven en contacto directo con ella» (Victorio, 1995: 50). 
hombre que no ha gozado de su amiga quien, además, acaba de casarse con otro $^{6}$. Nada más teatral.

\author{
Romance de Marquillos \\ ¡Cuán traidor eres, Marquillos! / ¿Cuán traidor de corazón! \\ Por dormir con tu señora / habías muerto a tu señor. \\ Desque lo tuviste muerto / quitástele el chapirón; \\ fuéraste al castillo fuerte / donde está la Blanca Flor. \\ -Ábreme, linda señora, / que aquí viene mi señor; \\ si no lo quieres creer, / veis aquí su chapirón. \\ Blanca Flor, desque lo viera, / las puertas luego le abrió; \\ echóle brazos al cuello, / allí luego la besó; \\ abrazándola y besando / a un palacio la metió. \\ -Marquillos, por Dios te ruego / que me otorgases un don: \\ que no durmieses conmigo / hasta que rayase el sol. \\ Marquillos, como es hidalgo, / el don luego le otorgó; \\ como viene tan cansado / en llegado se adurmió. \\ Levantóse muy ligera / la hermosa Blanca Flor, \\ tomara cuchillo en mano / y a Marquillos degolló.
}

Este romance es un buen ejemplo de cuanto venimos afirmando: la necesidad de entender y analizar la estructura y recursos teatrales para comprender y admirar la originalidad de unas composiciones de origen medieval que llegaron a ser, no sólo una de las más altas expresiones de poesía épicolírica literaria, sino una de las manifestaciones teatrales más populares y de mayor difusión y éxito en nuestro país.

Podemos leer este romance como una obra teatral breve, con intriga, suspense y un final dramático inesperado. Aparecen dos personajes en escena: Marquillos y Blanca Flor. Una voz nos advierte que Marquillos es un traidor que acaba de matar a su señor para acostarse con su señora, Blanca Flor. Se disfraza con las ropas del marido o señor de Blanca Flor (nada más teatral) y llama a las puertas de su castillo para que la dama le abra. Blanca Flor le abre y Marquillos la besa, la abraza y se la lleva a una alcoba. No sabemos si Blanca Flor ha sido engañada, si acepta el engaño o si le gusta el nuevo amante (intriga). Pero he aquí que Blanca Flor hace parar el juego erótico,

${ }^{6}$ La distinción clara entre «mujer» y «amiga» es otra de las curiosidades lingüísticas del poema, y que sea el hermano quien disponga de sus hermanas hasta el punto de ofrecerle a la más garrida de ellas al amigo para su consuelo, ya sea como mujer o como amiga, no deja de ser un dato de gran interés sociológico. 